\title{
Different properties of factor VIII in Von Willebrand's disease with respect to recovery in cryoprecipitate
}

Citation for published version (APA):

Stibbe, J., van der Plas, P. M., \& Hemker, H. C. (1974). Different properties of factor VIII in Von Willebrand's disease with respect to recovery in cryoprecipitate. Haemostasis, 3(3), 142-148. https://doi.org/10.1159/000214049

Document status and date:

Published: 01/01/1974

DOI:

10.1159/000214049

Document Version:

Publisher's PDF, also known as Version of record

\section{Please check the document version of this publication:}

- A submitted manuscript is the version of the article upon submission and before peer-review. There can be important differences between the submitted version and the official published version of record. People interested in the research are advised to contact the author for the final version of the publication, or visit the DOI to the publisher's website.

- The final author version and the galley proof are versions of the publication after peer review.

- The final published version features the final layout of the paper including the volume, issue and page numbers.

Link to publication

\footnotetext{
General rights rights.

- You may freely distribute the URL identifying the publication in the public portal. please follow below link for the End User Agreement:

www.umlib.nl/taverne-license

Take down policy

If you believe that this document breaches copyright please contact us at:

repository@maastrichtuniversity.nl

providing details and we will investigate your claim.
}

Copyright and moral rights for the publications made accessible in the public portal are retained by the authors and/or other copyright owners and it is a condition of accessing publications that users recognise and abide by the legal requirements associated with these

- Users may download and print one copy of any publication from the public portal for the purpose of private study or research.

- You may not further distribute the material or use it for any profit-making activity or commercial gain

If the publication is distributed under the terms of Article $25 \mathrm{fa}$ of the Dutch Copyright Act, indicated by the "Taverne" license above, 


\title{
Different Properties of Factor VIII in Von Willebrand's Disease with Respect to Recovery in Cryoprecipitate
}

\author{
J. Stibbe, P. M. van der Plas and H.C. Hemker \\ Department of Hematology, Division of Hemostasis, Erasmus University, Rotterdam, and \\ Laboratory of Cardiovascular and Blood Coagulation Biochemistry, Department of \\ Internal Medicine, University Medical Centre, Leiden
}

Keywords. Von Willebrand's disease - Hemophilia-A · Factor VIII - Factor VIIIrelated antigen $\cdot$ Bleeding factor $\cdot$ Cryoprecipitate

Abstract. The recovery of factor VIII-activity in cryoprecipitate prepared from plasma from six patients with von Willebrand's disease was low as compared to the recovery from normal and hemophilia-A plasma. The possible cause is briefly discussed.

Using a standardized method to prepare cryoprecipitate from small plasma samples it was found that the recovery of factor VIII-activity (F.VIII-act.) was low from plasma collected from patients with von Willebrand's disease (vWd). The results are reported and discussed.

\section{Materials and Methods}

Platelet-poor plasma (PPP). $5 \mathrm{ml}$ of blood was collected into polystyrene tubes containing $0.1 \mathrm{ml}$ sodium citrate $0.55 \mathrm{M}$, centrifuged immediately ( $10 \mathrm{~min}, 1,000 \mathrm{~g}$, room temperature) the plasma separated and centrifuged again $\left(25 \mathrm{~min}, 20.000 \mathrm{~g}, 4^{\circ} \mathrm{C}\right)$.

Preparation of cryoprecipitate. Immediately after the second centrifugation run, 2-ml samples of PPP were pipetted into polycarbonate centrifuge tubes, quickly frozen at $-30{ }^{\circ} \mathrm{C}$ in an ethanol/water mixture, stoppered and stored at $-70^{\circ} \mathrm{C}$ for $1-7$ days. The samples were then thawed for $1 \mathrm{~h}$ at $2{ }^{\circ} \mathrm{C}$ in a continuously stirred ethanol/water mixture. (Preliminary experiments showed that thawing for $45-120 \mathrm{~min}$ gave reproducible results.) The tubes were then centrifuged $\left(15 \mathrm{~min}, 20,000 \mathrm{~g}, 2^{\circ} \mathrm{C}\right)$ and the supernatant poured off. Remnants of supernatant were carefully removed with filter paper. The cryoprecipitate

Received: May 29, 1974; accepted: September 9, 1974. 


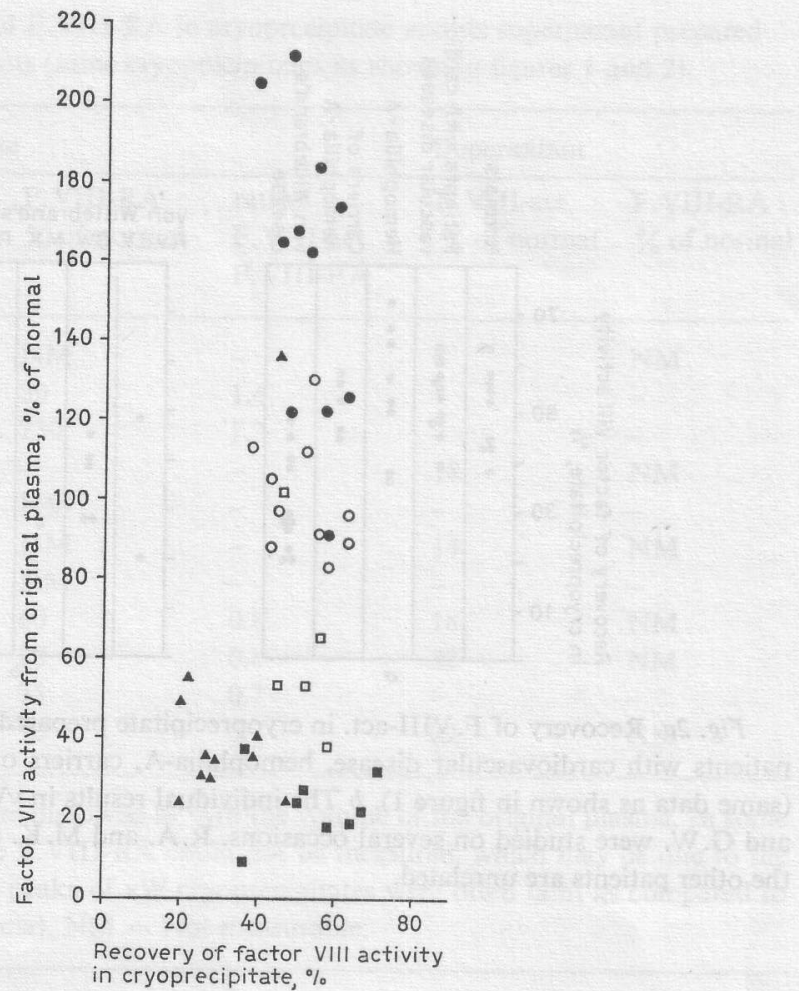

Fig. 1. Recovery of F. VIII-act. in cryoprecipitate prepared from normal, hemophilia-A and $\mathrm{vW}$ plasma. Proven carriers of hemophilia-A, who were known to have a low F. VIIIact. and patients with cardiovascular disease known to have a high F.VIII-act. were included to obtain a continuous scale of F. VIII-act. in the plasmas studied. $\mathrm{O}=$ Normals; - = patients with cardiovascular diseases; = hemophilia-A; $\square=$ carriers of hemophilia-A; $\nabla=$ von Willebrand's disease.

was dissolved in $0.4 \mathrm{ml}$ veronal buffer ( $\mathrm{pH} 7.42$ ). In 8 duplicate preparations of cryoprecipitate of plasma ( $4 \mathrm{vWd}$ and 4 normals) the mean error of recovery was $4.6 \%$. F. VIII-act. in supernatant and cryoprecipitate were measured immediately.

Factor VIII-related antigen (F.VIII-RA) was measured by the Laurell technique using rabbit anti-human factor VIII antiserum (Nordic, Tilburg). Pooled normal plasma was used as a standard. F. VIII-act. was assayed according to VeLTKAMP et al. [14] as modified by VeLtKAMP et al. [15]. Bleeding time according to IVY [3]. Retention of platelets in a glassbead column was measured according to SALZMAN [8]. 

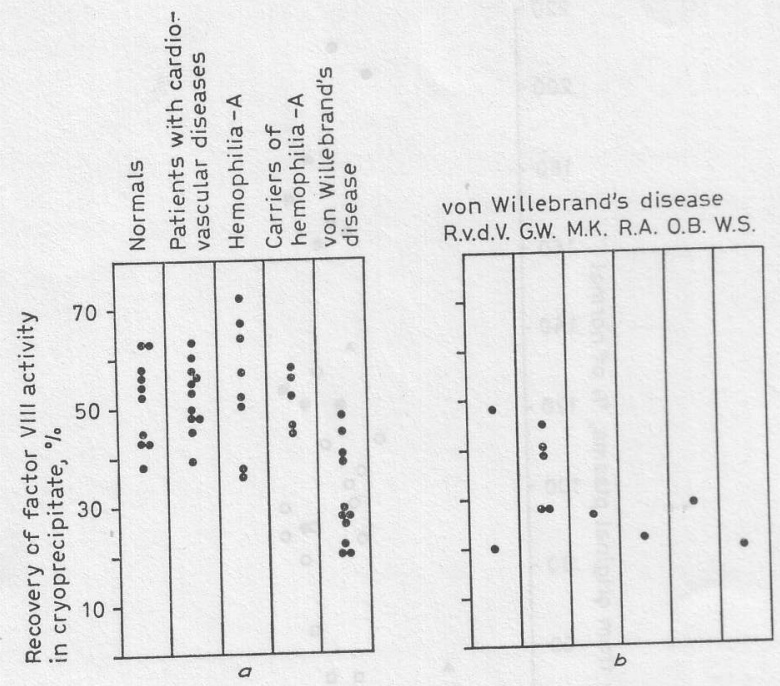

Fig. 2a. Recovery of F. VIII-act. in cryoprecipitate prepared from plasma of normals, patients with cardiovascular disease, hemophilia-A, carriers of hemophilia-A and vWd (same data as shown in figure 1). $b$ The individual results in vWd are shown. R. v. d. V. and G.W. were studied on several occasions. R.A. and M.K. are mother and daughter, the other patients are unrelated.

\section{Results}

Recovery of F. VIII-act. in cryoprecipitate prepared from vW plasma was found to be low as compared to the recovery from plasma from normals and hemophilia-A patients (fig. 1, 2a), The F. VIII-act. left in the supernatant was correspondingly higher in $\mathrm{vWd}$ (table I). There was no correlation between the F. VIII-act. in the original plasma and the recovery of it in the cryoprecipitate (fig. 1). In figure $2 \mathrm{~b}$ the recovery of F. VIII-act. in cryoprecipitate is shown separately for each of the six $v W$ patients studied. All $v W$ patients had low F. VIII-act. (see fig. 1), a strongly prolonged bleeding time and a low retention of platelets in the glassbead column. G. W. once showed a normal F. VIII-act. in her plasma ( $135 \%$ of normal) when she had an infectious disease. F. VIII-RA was measured in cryoprecipitate and supernatant (table I). In no instance could F. VIII-RA be measured in the supernatant. In cryoprecipitate the ratio biological activity/F. VIII-RA ranged from 0.7 to 1.4 . 
Table I. F. VIII-act. and F. VIII-RA in cryoprecipitate and its supernatant prepared from $6 \mathrm{vW}$ patients (same cryoprecipitates as shown in figures 1 and 2)

\begin{tabular}{llllll}
\hline \multirow{2}{*}{ Patient } & \multicolumn{2}{l}{ Cryoprecipitate } & \multicolumn{3}{c}{ Supernatant } \\
\cline { 2 - 6 } & $\begin{array}{lllll}\text { F. VIII-act. } \\
\% \text { of normal }\end{array}$ & $\begin{array}{l}\text { F. VIII-RA } \\
\% \text { of normal }\end{array}$ & $\begin{array}{l}\text { ratio } \\
\text { F. VIII-act } \\
\text { F. VIII-RA }\end{array}$ & $\begin{array}{l}\text { F. VIII-act. } \\
\% \text { of normal }\end{array}$ & $\begin{array}{l}\text { F. VIII-RA } \\
\% \text { of normal }\end{array}$ \\
\hline R.v.d.V. & 57 & NM & - & 8 & \\
G.W. & 42 & 30 & 1.4 & - & NM \\
& 304 & 230 & 1.3 & - & - \\
& 80 & - & - & 18 & NM \\
& 50 & NM & - & - & - \\
M.K. & 42 & NM & - & 14 & NM \\
R.A. & 48 & NM & - & - & - \\
O.B. & 40 & 60 & 0.8 & 18 & NM \\
W.S. & 65 & 80 & 0.8 & 32 & NM \\
\hline
\end{tabular}

The cryoprecipitates are dissolved in $1 / 5$ th the volume of the original plasma. In some of the cryoprecipitates the F. VIII-RA could not be measured, which may be due to the fact that the precipitation peaks of $\mathrm{vW}$ cryoprecipitates were often faint as compared to the standard (normal plasma). NM = Not measurable.

\section{Discussion}

There is accumulating evidence that F. VIII-act. is bound to more than one molecular form $[1,2,4,7,9,10,12,13,16,17]$ although it is questionable whether (part of) these reported forms reflect the native state of F.VIII.

In former experiments it was found by us that F. VIII-act. in plasma in vitro drops to about $50 \%$ of its initial value in about $10 \mathrm{~h}$ while during the following 4 days practically no further drop in activity was seen [10, 12]. The results were interpreted in this manner that F. VIII-act. was bound to two molecular forms which were interdependent [12]. One form then is labile (or converted to the other form in vitro), while the other is quite stable. In some patients with vWd the initial drop in F. VIII-act. was higher, being about $70 \%$ of the initial value. This was true for their own as well as transfusion-induced F. VIII-act. [10] suggesting different properties of F. VIII in those $\mathrm{vW}$ patients investigated as compared to normal F. VIII. 
WEISS and KocHWA [16] reported that normal plasma contained two molecular forms of F.VIII, a lower and a higher molecular weight form, while cryoprecipitate only contained the high molecular weight form. These results, combined with the finding that the F. VIII-act. in cryoprecipitate in comparable conditions as in plasma (normal cryoprecipitate dissolved in hemophilia-A plasma) is fairly stable [11] led us to assume that this high molecular weight form of F. VIII might be related or identical with the form which was recognized by us as stable. Following this reasoning and together with our former finding in $\mathrm{vWd}$, differences in cryoprecipitation of $\mathrm{vW}$ plasma were to expected. In fact, low recovery of F. VIII-act. and F. VIII-RA in several vW patients were reported [5]. Cryopecipitates were made under standardized conditions of six patients with $\mathrm{vWd}$ - several of them on different occasions - and compared with normals and hemophilia-A patients. In the vW patients the recovery was distinctly lower.

These results may be explained on basis of a hypothesis on the synthesis of F.VIII and the Bleeding factor (or von Willebrand factor) which was proposed by us in 1967 [10] to account for our finding that in vitro about $50 \%$ of the F. VIII-act. disappears quickly while the remaining activity is stable $[10,12]$ and at the same time could explain all phenomena seen in $\mathrm{vWd}$ and hemophilia-A. It was assumed that F. VIII was composed of two subunits, i.e. subunit $\alpha$ ( $\alpha$ for hemophilia- $A$ ), deficient or defective in hemophilia-A and subunit $\beta$ ( $\beta$ for Bleeding factor), deficient or defective in $\mathrm{vWd}$. Subunits $\alpha$ and $\beta$ are coded by a gene on the $X$ or an autosomal chromosome respectively. Subunit $\beta$ regulates the rate of synthesis or at least the release of subunit $\alpha$. The Bleeding factor activity was supposed to reside on the $\beta$ subunit. The F. VIII-RA as described later [18] was thought to be identical with the $\beta$ subunit. F. VIII-act. may be bound to the free $\alpha$ subunit, the combined $\alpha$ and $\beta$ subunit and/or polymers of it $\left(\alpha_{n} \beta_{m}\right)_{x}$, thus explaining the existence of two (or more) interdependent molecules showing F. VIII-act. Recently a hypothesis has been proposed by BLOom et al. [1] which has many similarities to ours. The high molecular weight and low molecular weight subunits in their hypothesis being comparable to our $\beta$ and $\alpha$ subunit, respectively.

A deficient or defective $\beta$ subunit - resulting in some type of $\mathrm{vWd}$ - may change the relative concentrations of the different forms of biological active F.VIII, or alternatively change the specific biological F. VIII-act. of one form, resulting in different recovery of the F. VIII-act. in cryoprecipitate. All $\mathrm{vW}$ patients investigated by us belonged to the same type of $\mathrm{vW}$ with regard to low F. VIII-act., strongly prolonged bleeding time and low retention of platelets in the glassbead column. 
The recovery of F. VIII-RA in cryoprecipitate may depend on the type of $\mathrm{vWd}$, namely the kind of defect of $\beta$ subunit or deficiency of it. KERNOFF et al. [6] reported a consistent low recovery of F. VIII-RA in cryoprecipitate prepared from plasma of one patient with $\mathrm{vWd}$ as compared to normal and hemophilia-A plasma. F. VIII-act. was not measured In five other vW patients the results were found to be more variable with what was thought to be probably due to the difficulty measuring low levels of F. VIII-RA. In our VW patients the ratio biological F. VIII-act./F. VIII-RA in the cryoprecipitate ranged from 0.7 to 1.4 (table I). Whether this broad range represents real differences or is due to technical difficulties is not known. One might expect that differences in molecular form will be reflected in the ratio biological activity/F. VIII-RA. It has to be recognized, however, that different molecular forms may differ in specific biological F. VIII-act. Furthermore, it is not known what fraction of the total $\beta$ subunit (i.e. of the total F. VIII-RA measured) occurs in a state not related to F. VIII-act., e. g. free and/or bound to inactivated $\alpha$ subunits. On the other hand, in the active $\left(\alpha_{\mathrm{n}} \beta_{\mathrm{m}}\right)_{\mathrm{x}}$ form, antigenic determinants of the $\beta$ subunit may be concealed.

\section{References}

1 Bloom, A.L.; Peake, I.R., and Giddings, J.C.: The presence and reactions of high and lower-molecular-weight procoagulant factor VIII in the plasma of patients with von Willebrand's disease after treatment: significance for a structural hypothesis for factor VIII. Thromb. Res. 3: 389-404 (1973).

2 CoOper, H.A.; GRIGGS, T.R., and WAGNeR, R.H.: Factor VIII recombination after dissociation by $\mathrm{CaCl}_{2}$. Proc. nat. Acad. Sci., Wash. 70: 2326-2329 (1973).

3 Ivy, A. C.; Nelson, D., and Bucher, G.: The standardization of certain factors in the cutaneous 'venostasis' bleeding time technique. J.Lab.clin. Med. 26: 1812-1819 (1941).

4 Van Mourik, J.; Bouma, B. N.; La Bruyère, W.T.; De Graaf, S., and Mochtar, I. A.: Factor VIII, a series of homologuous oligomers and a complex of two proteins. Thromb.Res. 4: 155-164 (1974).

5 KeRnoff, P.B.A. and RIZZA, C. R.: Letter to editor. Lancet. $i$ : 778 (1973).

6 Kernoff, P.B.A.; Gruson, R. and RizzA, C.R.: A variant of factor VIII-related antigen. Brit.J. Haemat. 26: 435-440 (1974).

7 RICK, M.E. and Hoyer, L.W.: Immunologic studies of antihemophilic factor (AHF, factor VIII). V. Immunologic properties of AHF subunits produced by salt dissociation. Blood 42: 737-747 (1973).

8 Salzman, E.W.: Measurement of platelet adhesiveness: a simple in vitro technique demonstrating an abnormality in von Willebrand's disease. J.Lab.clin.Med.62: 724735 (1963).

9 Shapiro, G.A.; ANDersen, J.C.; Pizzo, S. V., and McKee, P.A.: The subunit structure of normal and hemophilic fcator VIII. J.clin. Invest. 52: 2198-2210 (1973). 
10 STIBBE, J.: De inactivatie van factor VIII in vitro; thesis Amsterdam (1967).

11 Stibie, J.: Unpubl. results.

12 Stibbe, J.; Hemker, H.C., and Van Creveld, S.: The inactivation of factor VIII in vitro. Thromb. Diath. haemorrh. 27 : 43-58 (1972).

13 Thelin, G.M. and Wagner, R.H.: Sedimentation of plasma antihemophilic factor. Arch. Biochem. 95: 70-78 (1961).

14 VeltKamp, J.J.; Drion, E.F., and Loeliger, E.A.: Detection of the carrier state in hereditary coagulation disorders. Thromb. Diath.haemorrh. 19: 279-303 (1968).

15 VeltKamp, J.J. and VAN Tilburg, N.H.: Autosomal hemophilia: a variant of von Willebrand's disease. Brit. J. Haemat. 26: 141-152 (1974).

16 WeIss, H.J. and KocHWA, J.: Molecular forms of antihemophilic globulin in plasma, cryoprecipitate and after thrombin activation. Brit.J.Haemat. 18: 89-99 (1970).

17 Zimmermann, T.S. and Edington, T.S.: Factor VIII coagulant activity and factor VIII-like-antigen: independent molecular entities. J.exp. Med. 138: 1015-1020 (1973).

18 ZimmermanN, T.S.; RATNOFF, O.D., and Powel, A.E.: Immunologic differentiation of classic hemophilia (factor VIII deficiency) and von Willebrand's disease. J.clin. Invest. 50: 244-254 (1971).

Request reprints from: J.STIBBE, MD, Department of Hematology, Division of Hemostasis, Acad.Hospital Rotterdam-Dijkzigt, Rotterdam (The Netherlands) 